\title{
PENGARUH GOAL SETTING TERHADAP PERFORMANCE : TINJAUAN TEORITIS
}

\author{
Surya Dharma Ginting \\ D. Wahyu Ariani \\ Universitas Atma Jaya Yogyakarta
}

\begin{abstract}
This article is the conceptual view of goal setting theory and effects of goal setting on individual performance. Goal setting is recognized, and is a major theory of work motivation. Difficult goals have consistently been shown to lead to higher levels of performance than easy goals. If there is no commitment, a goal can have no motivational effect. Goals are central to current treatments of work motivation, and goal commitment is a necessary condition for difficult goals to result in higher task performance.
\end{abstract}

Keywords : goals, goal-setting theory, performance

\section{PENDAHULUAN}

Konsep "goal" adalah apa yang individu coba untuk mencapainya dan merupakan object atau tujuan dari suatu tindakan. Konsep ini mirip dengan pengertian konsep purpose atau intent. Dalam artikel Locke et al. (1981) dikatakan bahwa goal meliputi performance standard (standar kinerja, yaitu pengukuran untuk evaluasi kinerja), work norm (standar penerimaan terhadap perilaku tertentu yang ditentukan oleh kelompok kerja), quota (batas minimum dari kerja atau produksi), task (bagian pekerjaan yang dicapai), objective (tujuan akhir dari tindakan atau serangkaian tindakan), deadline (batas waktu penyelesaian tugas), dan budget (batas pengeluaran). Selain itu, goal seringkali disebut sebagai stimulus control. Namun hal ini hanya berlaku apabila hanya ada assign goal terhadap karyawan. Asumsi dasar penelitian goal setting adalah goal merupakan pengatur langsung tindakan manusia. Pengabungan yang tepat antara goals dan action merupakan pertanyaan empiris yang berkaitan dengan penelitian.

Artikel ini membahas konsep goal setting dan goal orientation dalam pencapaian individial performance dalam organisasi. Setelah bagian pertama yang berupa pendahuluan, bagian kedua artikel ini menguraikan tinjauan konseptual goal setting. Bagian ketiga menguraikan mekanisme pengaruh goal setting terhadap individual performance. Bagian keempat merupakan bagian terakhir yang akan menutup tulisan ini.

\section{TINJAUAN KONSEPTUAL GOAL SETTING DAN GOAL ORIENTATION}

Locke (1968) dalam Quick (1979) memandang goal setting sebagai teknik untuk meningkatkan motivasi kerja dan selanjutnya akan meningkatkan performance. Baik equity theory maupun VIE theory mengasumsikan bahwa persepsi orang-orang mengenai lingkungan kerja mereka menyebabkan mereka membentuk keyakinan dan perilaku (baik mengenai input, outcome, valences, expectancies, dan instrumentality) dan kognisi yang mempengaruhi work related behavior (Pinder, 1998). Namun, keterbatasan dalam memprediksi validitas pada equity theory dan VIE theory dapat dijelaskan dan merupakan bagian dari kegagalan yang menuju pada keinginan (intention). Goal setting merupakan prediktor work effort dan work performance dibanding dengan equity theory maupun VIE theory.

Namun, goal bukan sekedar intention, karena intention merupakan rencana suatu tindakan sedang goal menunjukkan tujuan atau sasaran suatu tindakan (Tubbs dan Ekeberg, 1991). Intention merupakan gambaran kognitif mengenai cara dan akhir, sehingga tergolong sebagai konsep goal. Fishbein dan Ajzen (1975) dalam Pinder (1998) mendefinisikan intention sebagai bentuk khusus dari belief, di mana intention adalah a belief linking a person (the object of belief) dan behavior (the attribute of belief) (Pinder, 1998). Menurut Ryan (1970) dalam Pinder (1998), intention adalah penyebab yang paling langsung dan paling penting 
dari behavior, sehingga untuk memahami people's intention memerlukan pemahaman mengenai cara orang memandang dunia sekitarnya. Prinsip dasar goal setting theory adalah goals dan intentions, yang keduanya merupakan penanggung jawab untuk human behavior. Goal merupakan sesuatu yang orang berusaha mencoba mendapatkan, mencapai, atau mengerjakan pekerjaannya. Dalam pekerjaan, goals dapat membentuk level of job performance, quota, work norm, deadline, atau budget. Apabila goals menentukan human effort, maka hal ini menunjukkan bahwa higher dari more difficult goals akan menghasilkan higher level of performance daripada yang dihasilkan oleh easy goals. Namun, orang dengan low goals confronting a task yang sulit ditangani akan menghasilkan frustasi yang sama seperti orang yang memiliki higher goals pada easy task.

Selanjutnya, menurut Locke et al. (1981), ada dua atribut dalam proses mental dalam individu, yaitu content dan intensity. Isu dari goal adalah obyek atau hasil yang dicari. Sementara dimensi goal content adalah specificity atau clarity (derajat ketepatan atau kejelasan kuantitatif dengan tujuan khusus) dan difficulty (derajat keahlian atau kinerja yang dicapai). Dalam artikel Locke et al. (1981), task difficulty dan goal difficulty merupakan dua istilah yang interchangeable, namun sebenarnya berbeda. Task merupakan bagian pekerjaan yang dicapai. Difficult task membutuhkan usaha yang keras untuk mengerjakannya. Tugas yang lebih berat disebabkan tugas tersebut membutuhkan level of skill dan knowledge yang tinggi dan membutuhkan usaha (effort) yang besar. Sementara goal merupakan tujuan atau sasaran dari suatu tindakan yang bisa untuk menyelesaikan tugas untuk mencapai tujuan. Dalam studi mengenai goal setting, goal menunjukkan pencapaian standar khusus dari suatu keahlian terhadap tugas dalam batasan waktu tertantu. Harder goal akan dapat tercapai bila ada usaha dan perhatian yang lebih besar dan membutuhkan lebih banyak knowledge dan skill daripada easy goal. Sehingga dapat dikatakan bahwa goal difficulty membutuhkan tingkat tertentu dari suatu keahlian tugas yang diukur dengan standar, sementara task difficulty menunjukkan kemudahan atau kesederhanaan suatu tugas untuk dapat dicapai. Hubungan antara task difficulty dengan performance merupakan problematik. Apabila kerja diterjemahkan ke dalam goal untuk dapat mengerjakan lebih banyak, maka task difficulty berhubungan positif dengan performance. Di sisi lain, bila harder tasks menghendaki lebih banyak kemampuan atau pengetahuan, banyak orang, paling tidak di bagian awal, akan melakukannnya dengan lebih keras dibanding dalam easier tasks.

Selanjutnya, meskipun ada berbagai pengaruh dimensi goal specificity dan goal difficulty terhadap performance, sedikit yang memperhatikan pada dimensi goal content yang lain, yaitu goal complexity dan goal conflict (Locke et al., 1981). Goal complexity adalah banyaknya hasil yang dituju dan hubungan antar hasil tersebut, sedangkan goal conflict adalah derajat pencapaian suatu suatu sasaran dengan meniadakan pencapaian sasaran yang lain. Atribut goal yang kedua adalah goal intensity. Intensitas ini diukur melalui faktor-faktor seperti lingkup dari cognitive process, derajat usaha (effort) yang dibutuhkan, pentingnya sasaran, dan konteks di mana sasaran disusun. Walaupun goal nitensity berhubungan dengan goal content, tetapi tidak banyak orang mempelajarinya, sedang goal commitment telah banyak diukur dengan sejumlah eksperimen.

Kemudian, dalam tinjauan literatur yang lebih awal mengenai goal setting, Locke (1968) menunjukkan bukti hubungan positif dan linier antara goal difficulty dan task performance (dengan asumsi kemampuannya memenuhi). Hal ini didukung oleh studi yang dilakukan akhir-akhir ini yang mendukung penemuan tersebut, bahwa harder goal membawa pada better performance daripada easier goal. Ada empat studi yang berhasil dikumpulkan oleh Locke et al. (1981) yang mendukung bahwa harder goals akan membawa pada better performance daripada easy goals. Dua puluh lima experimental laboratory studies juga mendapatkan hasil yang sama walaupun untuk setting tugas yang berbeda. Empat studi lain yang berhasil dikumpulkan Locke et al. (1981) menemukan dukungan kondisional untuk hubungan positif antara goal difficulty dan performance. Kempat studi tersebut menemukan bahwa hanya subyek yang mempunyai high goals dan yang menerima feedback yang berhubungan dengan kinerjanya yang berkaitan dengan pencapaian goals adalah lebih baik daripada subyek dengan low goals. Subyek dengan high goals dan moderately high goals yang sering menerima feedback, hasilnya lebih baik daripada subyek dengan average goals. Namun ada enam studi lainnya dengan eksperimen laboratorium yang berhasil dikumpulkan Locke et al. (1981) mengungkapkan hubungan negatif antara goal level dan performance. Locke et al. (1981) juga mendapati hasil penelitian 
Motowidlo et al. (1978) yang menguji kontroversi goal theory dan expectancy theory. Goal theory juga memprediksi bahwa harder goals akan membawa pada better performance daripada easy goals meskipun probabilitas tercapainya rendah. Di sisi lain, expectancy theory memprediksi hubungan positif antara expectancy dan performance, kebalikan dari prediksi goal theory. Motowidlo et al. (1978) dalam Locke et al. (1981) menemukan hubungan positif antara expectancy dan performance yang sesuai dengan expectancy theory.

Selain itu, Locke dan Latham (1990) dalam Seijts et al. ( 2004) menemukan adanya sejumlah variabel yang menunjukkan hubungan antara goal difficulty dan performance yang dibatasi oleh ability, feedback, task complexity dan situational constraint. (Oleh karenanya dapat dikatakan bahwa goal difficulty dapat meningkatkan performance bila ability, feedback, task complexity, dan situational constraint memenuhi standar atau persyaratan tertentu. Selain itu, Yukl dan Latham (1978) menemukan bahwa goals merupakan alat prediksi yang lebih baik bagi performance dan kepuasan kerja daripada pengukuran need for achievement (Seijts et al., 2004).

\section{MEKANISME PENGARUH GOAL SETTING TERHADAP INDIVIDUAL PERFORMANCE}

Selanjutnya, Locke (1968) mengusulkan a theory of task motivation mengenai pengaruh insentif seperti partisipasi dan knowledge of result dalam goal setting terhadap performance. Hal ini dikarenakan task performance tidak disebabkan secara langsung oleh insentif yang ada seperti knowledge of result dan participative goal setting, tetapi ditentukan oleh interpretasi kognitif dan evaluasi terhadap insentif dan goal aspiration yang disusun dari proses kognitif tersebut (Chacko dan Mc Elroy, 1983). Menurut mereka, goals juga dapat memediasi pengaruh insentif pada task performance. Kegiatan goal setting dalam organisasi membawa fungsi motivasi dan fungsi pembentukan peran (role making). Role making meliputi proses pendefinisian, penjelasan, dan pelaksanaan peran dalam organisasi Konsep ini melibatkan konsensus superior - subordinate yang mengenalkan derajat persetujuan antara kegiatan goal setting bagi supervisor dan employee. Quick (1979) dalam penelitiannya, memodifikasi model performance Locke (1968), sehingga task goals memediasi insentif dengan level of performance dan menggunakan dyadic goal setting superior subordinate dalam organisasi.. Task goals meliputi level of difficulty dan degree of clarity. Sementara insentif meliputi uang (money), performance feedback yang berupa knowledge of result, batas waktu (time limit), partisipasi, persaingan, dan konsekuensi perilaku dari performance level. Apabila digambarkan, maka pengaruh mediasi dari task goals tersebut nampak seperti Gambar 1.

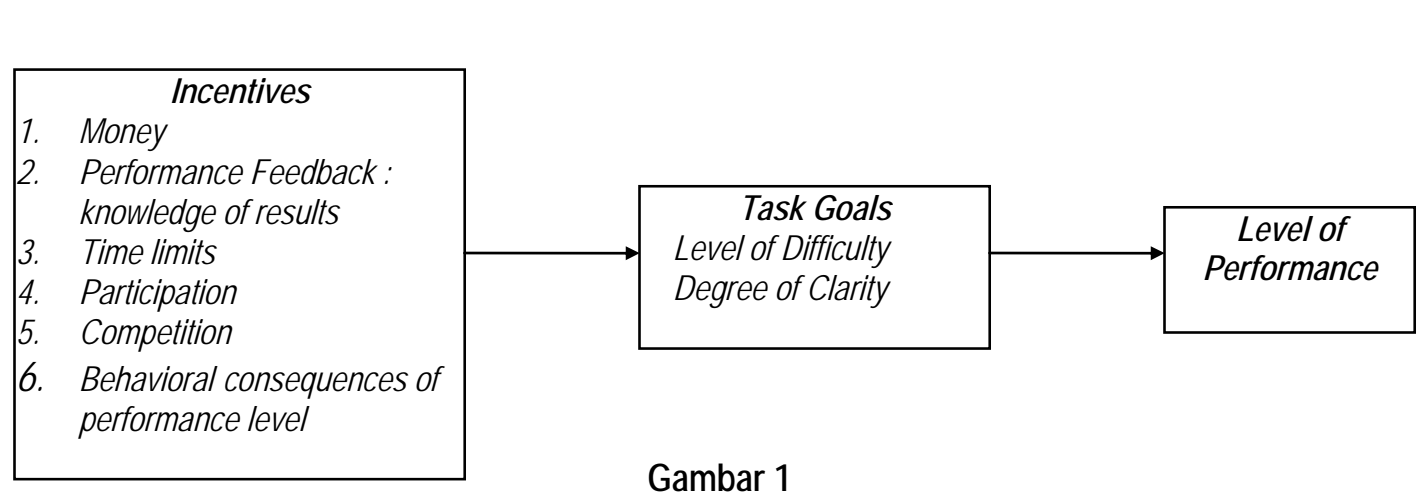

Sumber : Quick, 1979

A Modified Version of Locke's Task Performance Model

Hipotesis yang diuji oleh Locke (1968) adalah pengaruh knowledge of result dan partisipasi pada evaluasi dan kesadaran mental dari situasi tugas yang dihasilkan dalam goal aspiration. Selanjutnya, goal aspiration ini menentukan task performance. Meskipun demikian, peran dari evaluasi dan kesadaran mengenai intervening factor dalam partisipasi, hubungan knowledge of result dan goal aspiration tidak didukung maupun disangkal. Penelitian Chacko dan Mc Elroy (1983) menemukan beberapa hal, yaitu goal aspiration merupakan hasil evaluasi kognitif dari insentif atau dorongan lingkungan yang melibatkan causal attributions. Attribution 
theory berkaitan dengan persepsi, interpretasi, judgement, dan evaluasi peristiwa. Dalam teori atribusi, individu bertindak sebagai "naive" psychologist dan termotivasi untuk menguji penyebab suatu peristiwa untuk mendapatkan penjelasan kognitif dari struktur kausal lingkungannya. Menurut Weiner (1972), individu dalam pencapaian situasi menugaskan kausalitas untuk empat sumber, yaitu ability, effort, task difficulty, dan luck, serta yang bervariasi dalam dua dimensi, internal-external dan stable-unstable (Chacko dan Mc Elroy, 1983). Dari penelitian Chacko dan Mc Elroy (1983) ditemukan bahwa baik assigned goal setting ataupun participative goal setting mempunyai pengaruh positif terhadap goal aspiration, tergantung pada performance outcome dan cognitive explanation untuk performance tersebut. Selain itu, dukungan pada subordinate oleh manajer berpengaruh secara positif terhadap goals yang disusun individu. Dukungan ini akan menciptakan rasa percaya diri subordinate sehingga mempengaruhi cognitive response terhadap goal setting.

Selanjutnya, hasil penelitian Chacko danMc Elroy (1983) juga mengungkapkan bahwa baik participative goal setting maupun assigned goal setting dapat membawa pada higher goal levels hanya bila individu dapat membuat hubungan kognitif tertentu dengan performance. Orang akan sangat berbeda dari orang lain dalam kemampuan, pengetahuan, dan strategi yang digunakan untuk melaksanakan tugasnya. Goal setting theory mengasumsikan bahwa tindakan seseorang diarahkan oleh kesadaran akan adanya goal dan intention, tetapi tidak mengasumsikan bahwa semua tindakan manusia berada di bawah pengendalian penuh (Locke dan Latham, 1996). Ada kalanya, orang menolak assigned goal. Hal ini biasanya disebabkan mereka berpikir bahwa mereka tidak mampu mencapai goal tersebut karena kurang percaya diri, kurang mampu, tidak mempunyai pengetahuan yang cukup, dan seterusnya, atau mereka tidak dapat melihat berbagai keuntungan pribadi seperti kebanggaan, atau external reward seperti uang, promosi, dan seterusnya. Penyusunan goal secara partisipatif yang membawa pada kesuksesan akan menghasilkan high aspiration bila ability nampak sebagai penyebab performance. Meskipun demikian, performance outcome akan menjadi atribusi negatif untuk kemampuan (ability) akan menghasilkan low goal aspirations. Penggunaan assigned goal setting akan diperbaiki bila manajer secara kognitif menghubungkan good performance outcome dengan task difficulty dan poor performance outcome dengan kemungkinan sebab yang lain.

Penelitian Chacko dan Mc Elroy (1983) ini memang tidak dibahas dalam artikel Locke et al. (1981), karena batas waktu penelitiannya adalah tahun 1980, namun penelitian ini merupakan kelanjutan dari beberapa hasil penelitian yang telah dicatat oleh Locke et al. (1981). Dalam penelitian yang berhasil dikumpulkan Locke et al. (1981) belum dibahas goal aspiration. Selain itu, perbedaan participative goal setting dan assigned goals setting ada pada tingkat pendidikan subordinate, participative goal setting lebih tepat digunakan oleh uneducated worker, sedang assigned goal cocok bagi educated worker. Penelitian mengenai goal setting juga dilakukan oleh Kim (1984) yang menemukan penerapan goal setting dan feedback dalam organizational setting. Studi ini menemukan bahwa goal setting dan feedback yang diterapkan dalam organisasi tidak menyebabkan perceived goal attributes dan merupakan mediator yang signifikan. Program goal setting dan feedback secara simultan melibatkan perilaku dan outcome akan lebih unggul daripada perilaku sendiri atau outcome sendiri terhadap sales performance.

Selanjutnya, dalam artikel Locke et al. (1981) dikatakan bahwa penelitian mengenai goal conflict jarang dilakukan, sehingga tidak banyak dibahas dalam artikel tersebut. Padahal, goal conflict ini mempunyai pengaruh secara tidak langsung terhadap performance melalui hubungannya dengan goal commitment (Slocum et al., 2002). Goal conflict merupakan tahap di mana individu merasa bahwa multiple goals mereka incompatible atau bertentangan. Beberapa goal conflict yang telah diidentifikasi dengan cara antara lain bila secara eksternal menemukan goals yang bertentangan dengan personal goal seseorang, atau goal coflict terjadi bila orang harus mencari multiple outcome dalam melakukan tugasnya, atau goal conflict melibatkan trade off antara beberapa tipe tugas atau outcome bila ada multiple goals atau tasks exist. Menurut Slocum et al. (2002), goal conflict berhubungan negatif dengan goal commitment bila ada pengendalian terhadap antecedent lain, termasuk expectancy, self efficacy, dan need for achievement. Sebagai prediksi, goal commitment dan self efficacy berhubungan dengan goal directed behavior, lalu goal directed behavior berhubungan dengan kinerja. Goal commitment menunjukkan pencapaian atau penentuan untuk mencapai 
sasaran (Locke et al.,1988) yang mewujudkan sasaran dan ketidak inginan untuk menghilangkan atau menurunkan sasaran dari waktu ke waktu.

Selain itu, prinsip teori goal specificity dan goal difficulty mengasumsikan bahwa orang akan mempunyai komitmen terhadap goals yang memiliki cukup ability dan self efficacy yang berhubungan dengan tugas, dan bahwa feedback tersedia berkaitan dengan kemajuan terhadap goal tersebut. Komitmen memang harus ada dalam goal setting. Tanpa adanya komitmen maka berbagai fenomena tidak terjadi. Komitmen terhadap goal nampak secara langsung dan tidak langsung berpengaruh pada performance. Bila person's goal tinggi, maka high commitment akan membawa pada higher performance dibandingkan ketika low commitment. Tetapi, bila goals rendah, high commitment membatasi performance, karena orang yang mempunyai komitmen akan membenci peningkatan goalsnya dan orang yang tidak mempunyai komitmen akan menyusun goals terlalu tinggi. Tubbs (1993) menyatakan bahwa proses motivasi dalam goal setting berisi tiga tahapan, yaitu pertimbangan keterikatan dalam goal setting, perluasan usaha, dan ketepatan dalam memilih goal (Pinder, 1998). Namun demikian, pada tahap mana komitmen paling dibutuhkan untuk memoderasi hubungan antara goal dengan performance tidak dijelaskan.

Sementara itu, Locke dan Latham (1996) menyatakan bahwa goal commitment berdampak pada proses goal setting yang akan berkurang bila ada goal conflict. Hasil penelitian Slocum (2002) menyatakan bahwa goal commitment berhubungan positif dengan goal directed behavior, dan goal directed behavior berhubungan positif dengan performance. Hubungan tersebut signifikan secara statistik walaupun tidak sekuat hubungan self efficacy dengan goal directed behavior serta self efficacy dengan performance.

Kemudian, dalam artikel Locke et al. (1981) diungkapkan mengenai atribut dari proses mental, yaitu goal content dan goal intensity. Goal content terdiri dari goal specificity, goal clarity, goal complexity, dan goal conflict. Pinder (1998) mengungkapkan bahwa prinsip penting dalam teori goal setting adalah higher level of performance akan dicapai bila goal clarity dibuat spesifik (goal specificity). Selain itu, agar menjadi spesifik, goal harus dibuat sulit (goal difficulty). Apabila ditinjau dari sisi lain selain jenis penyusunan goal, performance dapat ditingkatkan bila ada persaingan (competition). Hal ini belum dibahas dalam artikel Locke et al. (1981). Ada dua alasan mengapa persaingan dapat menghasilkan higher performance. Pertama, competition dapat membangun komitmen terhadap goals untuk menyelesaikan tugas bagi individu. Kedua, competition dapat membantu penyusunan goal yang lebih sulit. Selain competition, faktor deadline bagi beberapa orang juga dapat meningkatkan performance. Hal ini disebabkan mereka akan bekerja lebih giat disaat mendekati deadline penyelesaian tugas. Goal setting theory juga menyatakan bahwa uang akan berpengaruh pada performance. Namun uang akan memotivasi higher level of performance hanya bila uang menghasilkan higher level of commitment. Menurut Latham dan Locke (1991), memang ada beberapa insentif yang dapat meningkatkan keberhasilan seseorang selain uang, yaitu partisipasi dalam pengambilan keputusan, job enrichment, behavior modification, dan organizational development.

Selanjutnya,dalam artikel Locke et al. (1981) diungkapkan bahwa pengaruh faktor kepribadian tidak nampak dalam goal setting, kalaupun ada, hanya need for achievement yang berpengaruh. Penelitian Latham danYukl (1975) yang diungkapkan dalam artikel Locke et al. (1981) tersebut menyatakan bahwa self esteem memoderasi pengaruh participative goals dan assigned goals pada kinerja, walaupun self esteem tersebut harus berinteraksi terlebih dahulu dengan goal instrumentality. Sementara itu, hasil penelitian Levy dan Baumgardner (1991) menyatakan bahwa self esteem dan gender berpengaruh dalam menyusun tujuan. Individu dengan high self esteem dan male participants akan memilih goals yang sulit dibandingkan individu yang low self esteem dan female participants. Bandura (1986) membedakan self esteem dengan self efficacy (Levy dan Baumgardner, 1991). Self efficacy berkaitan dengan judgment seseorang mengenai personal capabilities dalam domain tertentu, sementara self esteem berkaitan dengan evaluasi dari self worth. Levy dan Baumgardner (1991) lebih memilih menggunakan self esteem karena bersifat lebih luas daripada self efficacy, walaupun self efficacy lebih relevan dan merupakan prediktor yang lebih baik dalam goal choice daripada self esteem.

Hasil penelitian lain yang dilakukan oleh Appelbaum dan Hare (1996) menyatakan bahwa self efficacy merupakan social cognition construct atau social learning yang menunjukkan keyakinan seseorang terhadap 
kemampuannya dalam menyusun tugas tertentu dan merupakan prediktor bagi motivasi dan task performance, serta berpengaruh dalam personal goal setting individu. Self efficacy mempunyai empat dimensi, yaitu magnitude (tingkat kesulitan tugas yang diyakini untukdapat dicapai); strength (tingkat keyakinan bahwa tingkat kinerja tertentu dapat dicapai); dan generality (pertimbangan self-efficacy tertentu yang diterapkan dalam situasi yang berbeda). Self efficacy ini berkorelasi dengan predictive burnout, stress, supervisor ratings of performance, dan role adjustment dari new comers. Dalam goal setting, self efficacy ini merupakan faktor yang memediasi hubungan antara goal setting dengan performance.

Selanjutnya, penelitian mengenai berbagai faktor yang menyebabkan higher goals dalam goal setting masih berlanjut setelah tahun 1980. Pendapat Locke (1968) yang menyatakan bahwa specific goals menghasilkan greater effort daripada general goals, difficult goals menghasilkan greater effort daripada easier goals, dan feedback menghasilkan higher effort daripada the lack of feedback juga masih dianut hingga menghasilkan konsep Management by Objective (MBO). Secara konseptual, MBO mirip dengan goal setting theory dalam dukungannya pada specific goals dan feedback, sedangkan MBO berbeda dari goal setting theory dalam penekanan yang kuat pada partisipasi penyusunan tujuan (Terpstra dan Rozell, 1994). Mereka juga mengungkapkan bahwa baik secara kuantitatif maupun kualitatif. tinjauan penelitian menyimpulkan bahwa penerapan goal setting theory dapat meningkatkan tingkat usaha dan kinerja karyawan. Hasil penelitian Terpstra dan Rozell (1994) mengatakan bahwa tidak ada perbedaan yang signifikan secara statistik dalam menggunakan goal setting yang berhubungan dengan jenis industri maupun ukuran organisasi. Dengan kata lain, apapun jenis industrinya dan berapa pun besarnya organisasi, mereka mengatakan bahwa organisasi yang melakukan goal setting mempunyai secara signifikan greater profit and profit growth daripada organisasi yang tidak menerapkan goal setting. Hasil penelitian meerka juga menyatakan bahwa goal setting mempengaruhi secara positif outcome pada organisasi sebagai level of analysis, dengan menyatakan bahwa goal setting menyebabkan organisasi lebih profitable dan lebih efektif melalui motivasi individu dalam sales. Namun demikian, ada perkecualian dalam industri manufaktur. Dampak goal setting terhadap profitabilitas kurang nampak dalam industri manufaktur daripada industri lainnya. Perbedaan ini disebabkan karena faktor individu dalam menerima struktur tugas dan tingkat otomatisasi teknologi yang diterapkan.

Selanjutnya, apabila dalam artikel Locke et al. (1981) lebih banyak hasil penelitian yang dilakukan dengan assigned goal setting, Chacko, Stone,dan Brief (1979) mengatakan bahwa justru partisipasi yang telah banyak digunakan dalam mengambil keputusan ketika para anggota melakukan sharing dalam problem solving dan decision making. Selain itu, lebih banyak studi yang dilakukan berkaitan dengan group relationship, padahal yang lebih dapat dilihat pengaruh goal setting adalah bila menggunakan dyadic, superior subordinate relationship. Kegagalan dalam menemukan mengapa aspek-aspek dalam goal setting berhubungan ataupun tidak berhubungan dengan performance dan satisfaction juga jarang diuji dalam penelitian. Chacko et al. (1979) dan Chacko dan Mc Elroy (1983) telah menguji dengan menggunakan attribution theory. Mereka mengatakan bahwa penyebab pencapaian performance outcome dapat dipengaruhi oleh empat faktor, level of ability, amount of effort expended, level of difficulty of the task, dan amount of luck or chance factors experienced. Selain itu, attribution theory menyarankan bahwa high participation atau involvement dalam goal setting akan menyebabkan perasaan pengendalian dan berpengaruh pada goal dan outcome.

Kemudian, artikel Locke et al. (1981) yang menyatakan bahwa assigned goal setting yang lebih dapat memotivasi daripada participative goal setting mendapat dukungan dari Pinder (1998). Namun hal itu dianggap benar bila faktor-faktor lain yang mempengaruhinya konstan, seperti goal difficulty dan self efficacy. Secara keseluruhan dapat dikatakan bahwa partisipasi mempunyai pengaruh lemah dan tidak langsung terhadap performance. Namun Latham dan Locke (1991) menyatakan bahwa participative goal setting lebih unggul dibanding assigned goal setting dalam penyusunan higher goal dan dalam participative group yang karyawannya menuntut penyusunan goals yang sangat tinggi tanpa mengetahui bagaimana pencapaiannya di masa lalu.

Goal setting memang dapat dijumpai di berbagai penelitian. Lebih dari itu, Locke (1978) membagi adanya tiga kelompok teori yang didalamnya mencakup goal setting theory. Kelompok pertama adalah 
Scientific Management dan Management by Objective (MBO), yang secara eksplisit memperkenalkan pentingnya goal setting dalam teori dan praktek. Baik scientific management maupun management by objective memasukkan program tersebut ke dalam sistem pemberian penghargaan, sehingga individu termotivasi untuk mencapai goals-nya. Kelompok kedua adalah Human Relations dan Valence-InstrumentalityExpectancy (VIE) Theory, yang menyangkal pentingnya goal setting pada versi terdahulu tetapi mengakui pentingnya goal setting baik dalam teori dan praktek. Human relation mengakui bahwa keberhasilan manajer disebabkan adanya facts yang berkaitan dengan produksi dan feelings yang berkaitan dengan orang. Sementara itu, VIE theory gagal memperkenalkan pentingnya goal setting pada versi awal karena menekankan hedonisme. Namun, VIE theory yang mirip dengan human relation theory mengurangi penekannnya pada hedonisme diperluas dengan lebih menekankan pada diskusi, sehingga VIE theory memasukkan tahap goal setting di dalamnya, walaupun masih sering terjadi pertentangan antara VIE theory dan goal setting theory. Kelompok ketiga adalah Job Enrichment dan Organizational Behavior Modification (OB Mod), yang mempunyai konsistensi dalam mengakui relevansi goal setting dalam pernyataan teoritis yang resmi, tetapi telah mengakui pentingnya goal setting secara implisit melalui dukungan yang sesungguhnya dalam goal setting ketika teori tersebut dipraktekkan. Dalam praktek, goal setting dimasukkan ke dalam prosedur job enrichment dengan nama lain, yaitu feedback. Feedback memang tidak mempunyai kekuasaan memotivasi kinerja secara langsung, tetapi dapat memotivasi secara tidak langsung melalui hubungannya dengan goal setting.

Selanjutnya, penelitian yang dilakukan oleh Umstot, Bell, dan Mitchell (1976) yang menemukan bahwa prosedur job enrichment yang telah menghapus elemen-elemen goal setting akan membawa pada peningkatan job satisfaction tetapi gagal dalam meningkatkan produktivitas (Locke dan Latham, 1996). Di sisi lain, adanya penugasan kepada karyawan secara eksplisit, maka goals yang menantang digabungkan dengan feedback akan membawa pada higher productivity tanpa adanya job enrichment. Bila goal setting dan job enrichment digabungkan, maka produktivitas dan job satisfaction meningkat. Walaupun demikian, greater satisfaction sebenarnya berasal dari keyakinan seseorang bahwa ia bertanggung jawab terhadap hasil dari goal oriented behavior dan menekankan pada person's self efficacy. Dari berbagai pemaparan Locke (1978), disimpulkan bahwa goal setting hanya merupakan elemen dalam teori-teori yang membantu memotivasi performance karyawan tetapi hanya bila goal setting merupakan satu hal yang terpenting. Elemen motivasi lainnya seperti insentif, partisipasi, dan otonomi dapat mempengaruhi komitmen karyawan dan kemauan untuk menyusun goals yang akan memotivasi mereka. Selain itu, banyak karyawan akan menolak assigned goals bila goals tersebut tidak berkaitan dengan insentif. Penerimaan karyawan terhadap assigned goals juga dipengaruhi oleh fairness and difficulty of goals, value of the employees, their trust of management, dan perceived legimacy of management's demands.

Selain itu, dalam artikel Locke et al. (1981), goal commitment telah dibahas sebagai kondisi yang mempengaruhi hubungan goal setting dengan performance. Locke, Latham, dan Erez (1988) melanjutkan hasil penelitian yang telah dikumpulkan Locke et al. (1981). Namun masalah yang dihadapi dalam pengukuran komitmen nampak bila komitmen mempengaruhi performance tetapi tidak dapat dilaporkan secara akurat (Locke et al., 1988). Dalam penelitian mereka dikatakan bahwa baik penelitian teoritis maupun empiris menyatakan bahwa memang ada hubungan antara goal commitment dengan performance, sehingga diperlukan pemahaman mengenai faktor-faktor yang mempengaruhi goal commitment. Menurut Locke et al. (1988), penentu komitmen dapat digolongkan menjadi external influences (authority, peer influence, dan external rewards); interactive influences (participatition dan competition); serta internal factors (expectancy dan internal rewards). Hal ini dapat digambarkan seperti Gambar 2.

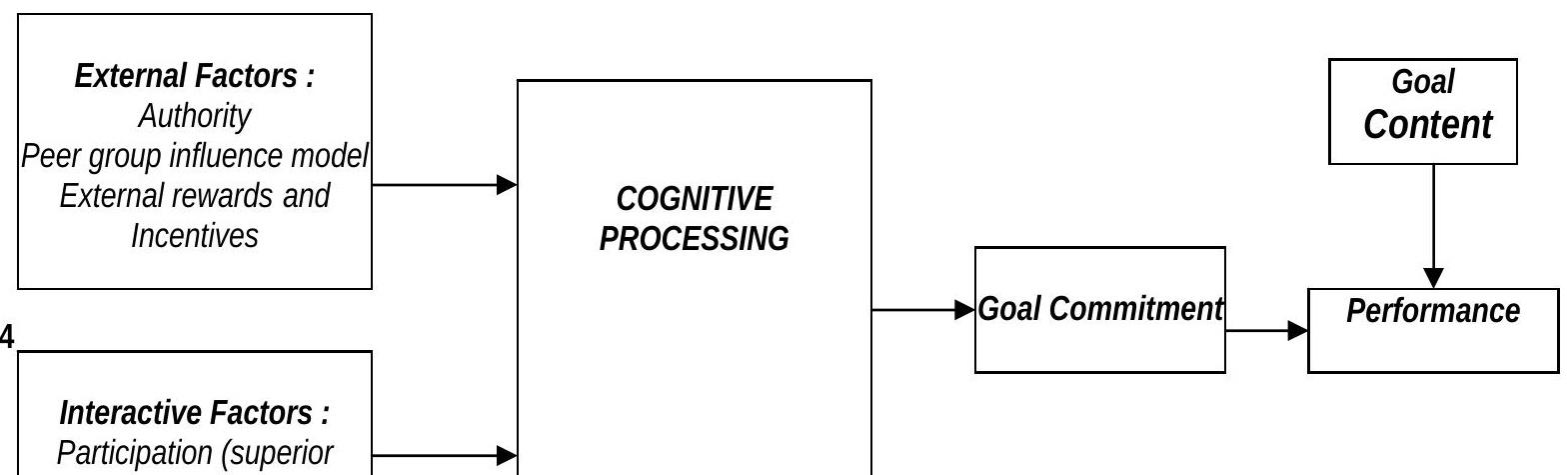




\section{Gambar 2 \\ Goal Commitment Model}

Dari Gambar 2 tersebut nampak bahwa ada hubungan yang logis antara goal commitment dan performance. Secara keseluruhan, dapat dikatakan bahwa intentions atau goals dipengaruhi oleh berbagai faktor, yaitu belief dan attitude. Menurut Locke et al. (1981), jika tidak ada komitmen, goal tidak mempunyai motivational effect. Selain itu, meskipun goal commitment memainkan peran konseptual inti dalam pengembangan task goal theory, namun pengujian goal commitment seringkali tidak dilakukan dalam penelitian goal-setting (Klein et al., 1999).

Selanjutnya, goals merupakan kesatuan dari teori-teori motivasi yang menekankan pada selfregulation dan mencakup task goal theory, social-cognitive thaory, resource allocation theory, dan control theory (Klein et al., 1999). Teori-teori tersebut berbeda, namun semuanya memandang goals sebagai penentu utama motivasi. Hubungan antara persepsi, keyakinan, sikap, keinginan (intention), dan perilaku kerja dari tiga teori (equity theory, VIE theory, dan goal setting theory) dapat digambarkan seperti Gambar 3. 


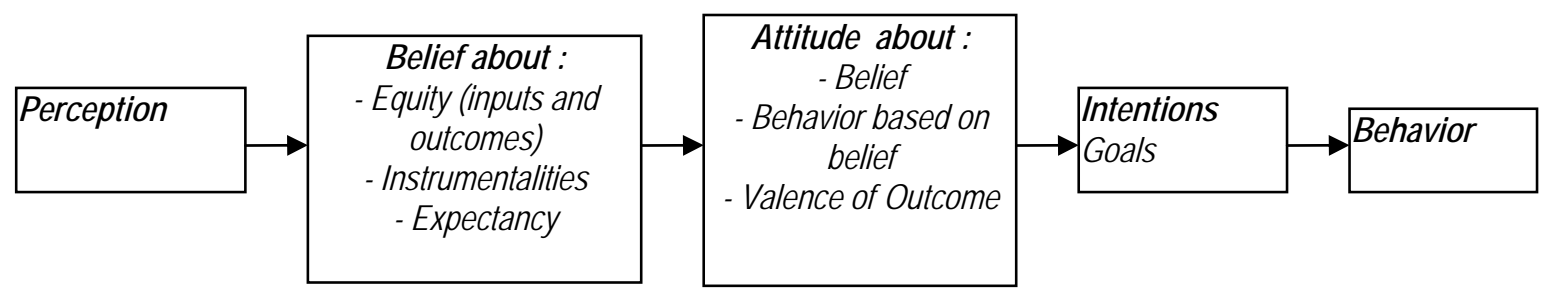

Sumber : Pinder, 1998

\section{Gambar 3}

The Relationship among Belief, Attitudes, and Behavior

Kemudian, dari berbagai hal yang berkaitan dengan goal setting yang telah dipaparkan di atas, maka Latham dan Locke (1991) menggambarkan model hubungannya seperti pada Gambar 4.

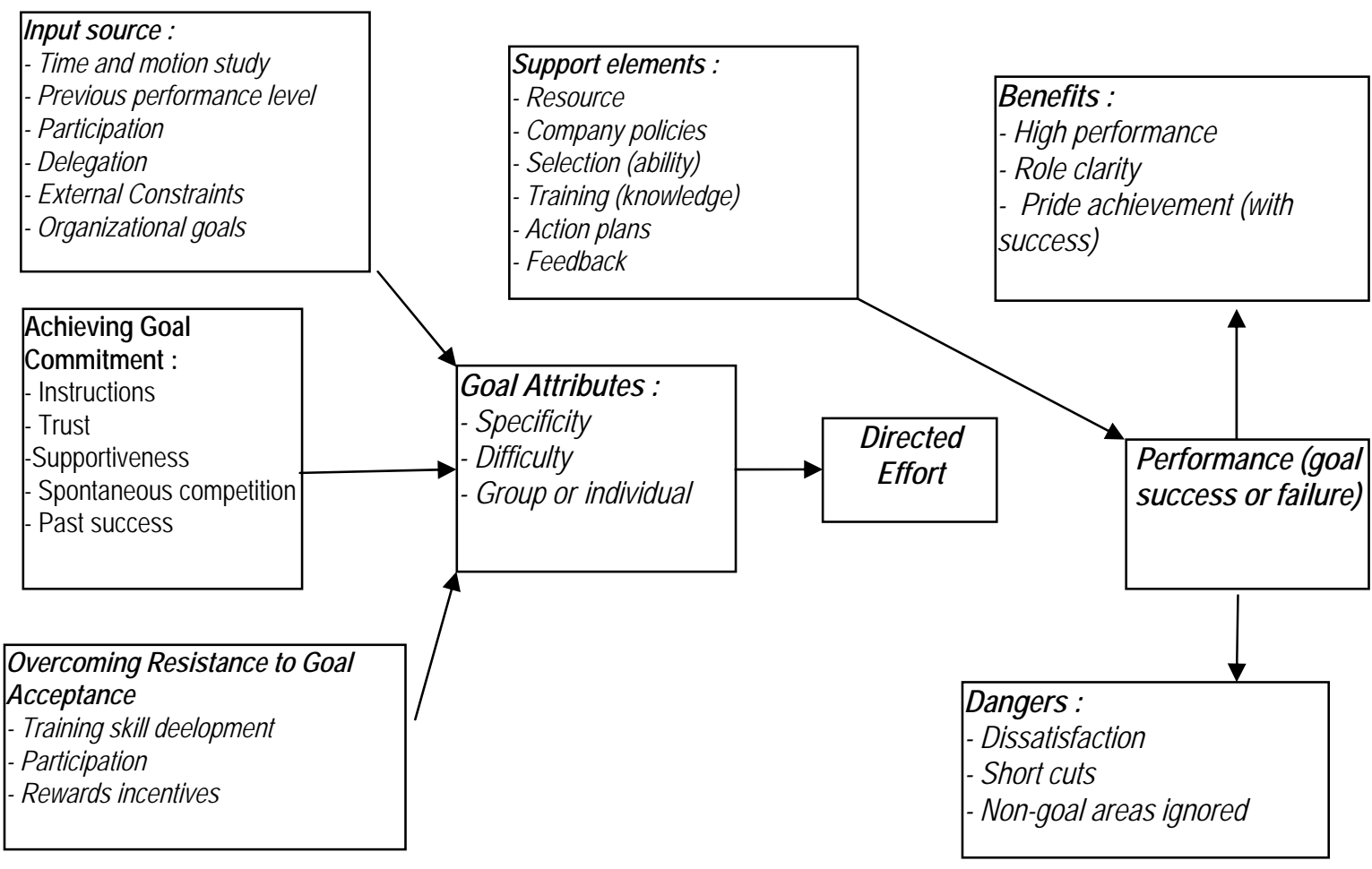

Sumber : Latham and Locke, 1991

\section{Gambar 4 \\ Goal Setting Model}




\section{PENUTUP}

Dari berbagai paparan mengenai goal setting theory, yang perlu dicatat adalah resep goal setting berkaitan dengan optimum level of difficulty yang berbeda dengan yang berasal dari VIE theory (yang menyarankan bahwa motivasi maksimum bila expectancy belief maksimum) dan pandangan Mc Clelland dan Atkinson yang pencapaian motivasinya maksimum bila individu mempersepsikan tugas pada level kesulitan sedang. Selain itu, pengaruh yang bermanfaat dari goal setting terhadap task performance merupakan hasil temuan yang robust dan telah direplikasi dalam banyak penelitian. Goal setting theory merupakan teori motivasi yang lebih terfokus daripada teori motivasi lainnya.

Ada minimal empat mekanisme di mana goal mempengaruhi task performance, yaitu melalui pengarahan perhatian dan tindakan, pengerahan usaha, memperpanjang usaha dari waktu ke waktu atau ketepatan, dan motivasi individu untuk pengembangan strategi yang relevan untuk pencapaian goal. Selain itu, ada beberapa hal yang berpengaruh dalam hubungan antara goal dan performance, yaitu range and type of goals, goal specificity, ability, knowewdge of resulys, monetary rewards, participation and supportiveness, individual differences, goal acceptance and choice, goal commitment, indifidual differences, dan isu-isu lain control, competition, self-rewards, conflict situation, dan masih banyak lagi.

\section{DAFTAR PUSTAKA}

Appelbaum, S.H. dan Hare, A. (1996), "Self-Efficacy as a Mediator of Goal Setting and Performance Some Human Resource Applications", Journal of Managerial Psychology, 11 , 33-45

Chacko, T.I. dan Mc Elroy, J.C. (1983), "The Cognitive Component In Locke's Theory of Goal Setting : Suggestive Evidence for a Causal Attribution Interpretation", Academy of Management Journal, 26 (1), 104-118

Chacko,T.I.; Stone, T.H. ; dan Brief, A.P. (1979), "Participation In Goal-Setting Program : An Attributional Analysis", Academy of Management Review, Juli, 433-438

Kim, J.S. (1984), "Effect of Behavior Plus Outcome Goal Setting and Feedback on Employee satisfaction and Performance", Academy of Management Journal, 27 (1), 139-149

Klein, H.J.; Wesson, M.J.; Hollenback, J.R.; dan Alge, B.J. (1999), "Goal Commitment and Goal-Setting Process : Conceptual Clarification and Empirical Synthesis", Joumal of Applied Psychology, 9184 (6), 885-896

Latham, G.P. dan Locke, E.A. (1991), "Goal Setting - A Motivational Technique That Works", Dalam Staw, B.M. (editor), Psychological Dimensions of Organizational Behavior, 54-64. New York : Macmillan Publishing Company

Levy, P.E. dan Baugardner, A.H. (1991), "Effects of Self-Esteem and Gender on Goal Choice", Journal of Organizational Behavior, 12 (6), 529-541

Locke, E.A. (1978), "The Ubiquity of The Technique of Goal Setting in Theories of and Approaches to Employee Motivation", Academy of Management Review, July, 594-601

Locke, E.A. dan Latham, G.P. (1996), "Goal Setting Theory : An Introduction. Dalam Steers, Porter, dan Bigley", Motivation and Leadership at Work, 95-121. New York : McGraw-Hill Companies. Inc.

Locke, E.A.; Latham, G.P.; dan Erez, M. (1988), "The Determinants of Goal Commitment", Academy of Management Review, $13(1), 23-39$

Locke, E.A.; Shaw, K.N.; Saari, L.M.; dan Latham, G.P. (1981), "Goal Setting and Task Performance : 1969 -1980", Psychological Bulletin, 90 (1), 125-152

Pinder, C.C. (1998), Work Motivation and Organizational Behavior. Ney Jersey : Prentice Hall 
Quick, J.C. (1979), "Dyadic Goal Setting Within Organizations : Role-Making and Motivational Considerations", Academy of Management Review, July, 369-380

Slocum, J.W.; Cron, W.L.; dan Brown, S.P. (2002), "The Effect of Goal Conflict on Performance", Journal of Leadership and Organizational Studies, 9 (1), 78-89

Seijts, G.H.; Latham, G.P.; Tasa, K.; dan Latham, B.W. (2004), "Goal Setting and Goal Orientation : An Integration of Two Different Yet Related Literature", Academy of Management Journal, 47 (2), 227-239

Terpstra, D.E. dan Rozell, E.J. (1994), "The Relationship of Goal Setting to Organizational Profitability", Group \& Organization Management, 19 (3), September, 285-294

Tubbs, M.E. dan Ekeberg, S.E. (1991), "The Role of Intentions in Work Motivation : Implications For Goal-Setting Theory and Research", Academy of Management Review, 16 (1), 180-199 